\title{
REPLACEMENT OF $\mathrm{TiO}_{2}$ PIGMENT BY $\mathrm{CaCO}_{3}$ FROM CEFALONIA IN EMULSION PAINTS
}

\author{
Kalafati K. ${ }^{1}$, and Christidis G. E. ${ }^{1}$ \\ ${ }^{I}$ Technical University of Crete, Department of Minerals Resource Engineering, 73100 Chania, \\ Greece,Konstantina.Kalafati@ikng.com,christid@mred.tuc.gr
}

\begin{abstract}
The purpose of this work is to show that calcium carbonate from the chalky limestone deposits of Minies in Kefalonia, exploited by IONIAN KALK S.A., is a suitable raw material for paint industry and especially in emulsion (water based) paints. The deposit is characterized by a high calcium carbonate content (>99\%), high whiteness and low yellowness, by negligible content of heavy metals and low contents of $\mathrm{MgO}(<0.15 \%), \mathrm{SiO} 2(<0.05 \%)$ and $\mathrm{Fe} 2 \mathrm{O} 3(<0.01 \%)$. This research was based on determination of the optical and mechanical properties of the emulsion white water based paints, which included calcium carbonate from the Kefalonia limestone deposits. The calcium carbonate replaced $\mathrm{TiO}_{2}$ pigment in various proportions. It is concluded that this product can be utilized not only as inert filler and extender but may have more functional application acting simultaneously as pigment. Replacement of $\mathrm{TiO}_{2}$ pigment by calcium carbonate may reach 50\% without deteriorating the optical and mechanical properties significantly. Hence calcium carbonate from this deposit offers excellent optical properties to paints, reduces sufficiently their production cost and replaces a great part of the proportion of titanium dioxide, which is currently used as white pigment.
\end{abstract} Key words: calcium carbonate, pigments, $\mathrm{TiO}_{2}$, emulsion paints.

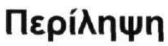

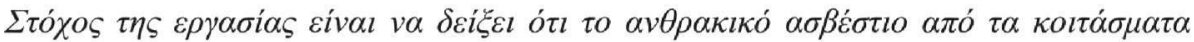

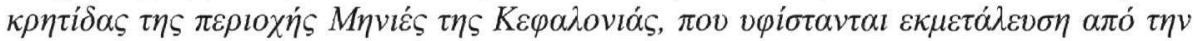

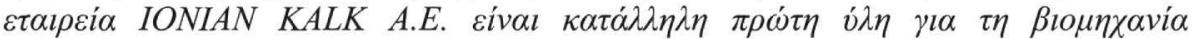

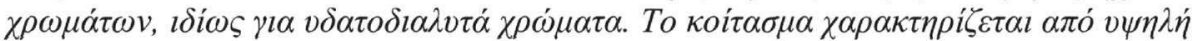

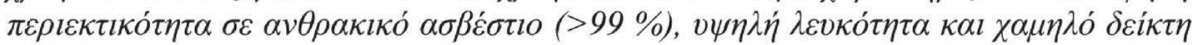

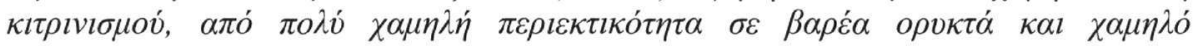

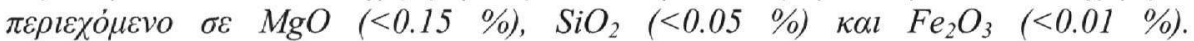

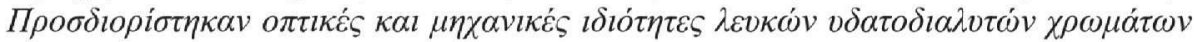

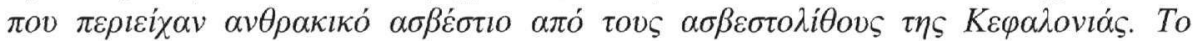

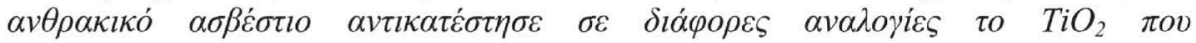

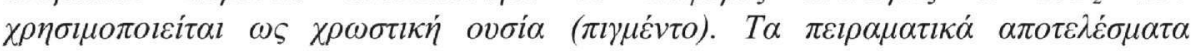

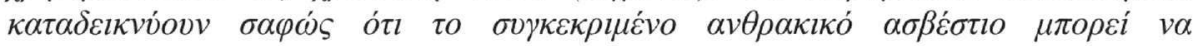

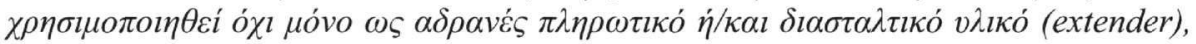

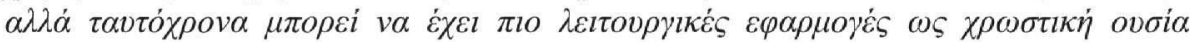

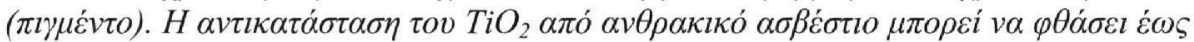

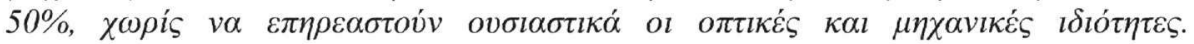




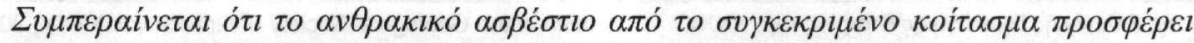

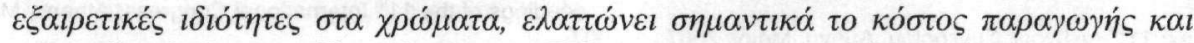

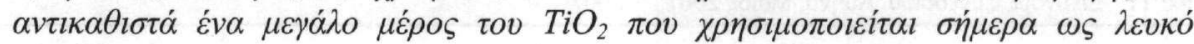
$\pi \imath \gamma \mu \varepsilon \dot{v} \tau o$.

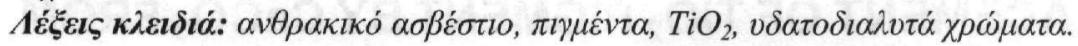

\section{Introduction}

Naturally occurring carbonate rocks, including limestone, dolomite, chalk, marble, travertine, vein calcite etc, have been considered very important raw materials for thousands of years in various applications (eg. Boynton 1980, Scott and Dunham 1984, Power 1985, Carr et al. 1994). Calcium Carbonate (CC), is a very common industrial mineral utilized as a filler and extender in plastic, paper and paint industry (Scott and Dunham 1984, Naydowski et al. 2001). Over the last years global production of $\mathrm{CC}$ has increased and competition has risen at even higher levels. Filler producers need to make their products more competitive by setting stricter specifications and higher quality characteristics, always with the minimum production cost. The performance of industrial fillers results both from the inherent characteristics of the mineral itself and from the nature of the impurities present (e.g. colouring impurities such as organic matter and various types of free oxides like iron titanium and manganese oxides) and the characteristics imparted by processing, e.g., beneficiation, grinding, classification, calcination, slurring, surface treatment (Christidis et al. 2004). Important properties of fillers include hardness, particle size and shape, colour, refractive index and chemical properties.

An important specification for calcium carbonate filler is high $\mathrm{CaCO}_{3}$ content; the minimum $\mathrm{CaCO}_{3}$ content allowed is $98.5 \%$. This is because any beneficiation to separate and remove all impurities increase considerably production cost. It is the purpose of this paper to show how optical and mechanical properties of calcium carbonate affect directly the respective properties of the emulsion paint, which contains that filler. Calcium carbonate filler is a versatile product in paint industry that moves beyond its inert role as a mere filling compound and can be applied as an extender and pigment as well.

\section{Colour measurement and optical properties of coatings-the CIELAB system}

The CIELAB colour system is the most suitable method of measuring object or surface colour properties. The main colour parameters determined by the CIELAB colour system are the parameters: $\mathrm{L}^{*}$, which represents lightness on a scale of 0 (black) to 100 (pure white); $\mathrm{a}^{*}$ which is the degree of redness if positive or greenness it negative; $b^{*}$ which is the degree of yellowness if positive or blueness if negative (Billmeyer and Saltzman 1981). The CIELAB values are calculated from the red green and blue filters of the colorimeters and are particularly suited to describing near white samples according to the following equations:

$\mathrm{L}^{*}=116\left(\mathrm{Y} / \mathrm{Y}^{\mathrm{n}}\right)^{1 / 3}-16$

$a^{*}=200\left[\left(\left(X / X^{n}\right)^{1 / 3}-\left(Y / Y^{n}\right)^{1 / 3}\right]\right.$

$\mathrm{b}^{*}=200\left[\left(\left(\mathrm{Z} / \mathrm{Z}^{\mathrm{n}}\right)^{1 / 3}-\left(\mathrm{Y} / \mathrm{Y}^{\mathrm{n}}\right)^{1 / 3}\right]\right.$

where $\mathrm{X}, \mathrm{Y}$ and $\mathrm{Z}$ are the tristimulus values for the samples arising from the colourimetric system and $\mathrm{X}^{\mathrm{n}}, \mathrm{Y}^{\mathrm{n}}$ and $\mathrm{Z}^{\mathrm{n}}$ are those of a surface colour chosen as the nominal white stimulus. In this study we used $\mathrm{BaSO}_{4}$, as a standard white material. Another useful parameter for describing white, which is given in the BS 3900 (1986) is $\Delta \mathrm{E}^{*} \mathrm{ab}$. This index, describes the difference between the colour of a sample and pure white, using the values of $\mathrm{L}^{*} \mathrm{a}^{*}$ and $\mathrm{b}^{*}$.

The most important optical properties of coatings, which are applied in special cards in the form of films with thickness $150 \mu \mathrm{m}$ and $300 \mu \mathrm{m}$, are the following: 
$\mathrm{R}_{\mathrm{X}}, \mathrm{R}_{\mathrm{Y}}$ and $\mathrm{R}_{\mathrm{Z}}$. They correspond to the $\mathrm{X}, \mathrm{Y}$ and $\mathrm{Z}$ tristimulus values described previously, and are measured on the white area of a card. $R_{Y}$ value can be measured in black area as well; it is then referred black or white correspondingly.

Yellowness index $b^{*}$ described before.

Contrast-ratio, which shows the opacity of a coating and is calculated according to the equation:

Contrast Ratio $=\mathrm{R}_{\mathrm{Y}}$ (black) $/ \mathrm{R}_{\mathrm{Y}}$ (white) $* 100$

Gloss, measured with glossmeter and calculated from the equation:

$\mathrm{G}=\mathrm{V}_{\text {sample }} / \mathrm{V}_{\text {standard }}$

Where $V_{\text {samplec }}$ and $V_{\text {standard }}$ are functions of the angle $(\theta)$ of the incident or reflected beam.

\section{Mechanical properties of surface coatings}

Mechanical properties of coating that were measured in this research are Wet Scrub Resistance and Film Density of the coating.

Wet Scrub Resistance provides an indication of the life time of the film and its resistance to strain conditions. It measures the endurance of a colour in washing. It is affected directly from the fillers and the binder. Film Density is calculated from the equation $\mathrm{d}=\mathrm{m} / \mathrm{V}$, where $\mathrm{d}$ is the film density, and $\mathrm{m}$ and $\mathrm{V}$ are mass and volume of the film respectively. Film Density is very important property because it is linked direct with the opacity of a coating, which determines how much light can pass through the film. Film Density and thus the opacity of a coating depends directly on the particle size of the fillers. Finer fillers will provide lower density in the film compared to a coarser filler. This is explained by the fact that the volume of a finer filler is much greater than the volume of a coarser filler.

Optical and mechanical properties of coatings are measured on the film that coating creates when applied. These properties are measured on special cards with glossy surface. Half of their surface is coloured white and other half black. These cards have been established to be used for the measurement of the optical properties of the coatings in order to be objective comparing means for different colours. On these cards the coating is applied and the film is created. The thickness of the film is usually $150 \mu \mathrm{m}$ and $300 \mu \mathrm{m}$.

\section{Materials and methods}

\subsection{Calcium Carbonate and $\mathrm{TiO}_{2}$ pigment}

The source of calcium carbonate is an ultra-high purity micritic limestone from Kefalonia Island in Western Greece. The material, which is produced by IONIAN KALK SA, is derived from an Eocene-Oligocene unbedded chalk, with scattered intercalations of chert nodules. The maximum diameter of the nodules varies from a few $\mathrm{mm}$ to $\mathrm{ca} 1 \mathrm{~m}$. The nodules are removed selectively during extraction (IONIAN KALK SA pers. comm.). The limestone outcrop is extended and is usually fractured and strongly karstified in the upper horizons. It belongs to the Paxos Geotectonic Unit and has maximum thickness $100 \mathrm{~m}$ (Bergmann 1964). The limestone contains $99.70 \%$ calcite, it has a high porosity (ca. $20 \%$ ) and average calcite crystal size $4.1 \mu \mathrm{m}$ in situ (Christidis et al. 2004). Minor mineralogical constituents which constitute the insoluble residue are quartz and opaque minerals (colouring agents), ferric chromite and ilmenite and to a lesser degree sphalerite and chalcopyrite. Pyrite is absent. In the present study the material used was an industrial product with median grain size $d_{50} 0.75 \mu \mathrm{m}$ and $d_{98} 3.5 \mu \mathrm{m}$, prepared by IONIAN KALK SA. The optical properties of this filler was $L^{*}=98.5$ and $b^{*}=1.0$.

The $\mathrm{TiO}_{2}$ used was rutile (Tiona 595, with $\mathrm{D}_{98} 0.7 \mu \mathrm{m}$ and $\mathrm{D}_{50} 0.25 \mu \mathrm{m}$ produced by Millennium Inorganic Chemicals) coated with $\mathrm{Al}_{2} \mathrm{O}_{3}, \mathrm{ZrO}_{2}$ and organic compounds and was provided by 
OMYA S.A. The material is a white pigment which provides in paints great coverage, gloss and white colour. Maximum particle size was $0.7 \mu \mathrm{m}$ and mean particle size $0.25 \mu \mathrm{m}$. The optical properties of this filler was $L^{*}=96$ and $b^{*}=1,7$. The characteristics and suppliers of the various chemicals used for the formulation of paints are listed in Table 1.

\subsection{Colour and optical measurements}

The colour properties of the end member ground materials and their mixtures were measured according to the CIELAB system using a Data Color $600+$ dual beam reflectance spectrophotometer with diffuse illumination and $8^{\circ}$ viewing geometry and illuminant "D65" source. The spectrophotometer was calibrated against $\mathrm{BaSO}_{4}$ standard. $\mathrm{Rx}, \mathrm{Ry}$ and $\mathrm{Rz}$ values, contrast ratio and gloss of film coatings was measured with a colour-gloss meter of BYK Gardner.

Table 1 - Characteristics and suppliers of the chemical compounds used to formulate the paints applied in this study

\begin{tabular}{|c|c|c|c|}
\hline Commercial Product & Company & Type & Application \\
\hline Tylose MH 30000 YG8 & Clariant $\mathrm{GmbH}$ & $\begin{array}{l}\text { Methyl } \\
\text { hydroxyethyl } \\
\text { cellulose }\end{array}$ & Thickening agent \\
\hline Sodium hydroxide, $10 \%$ & Siegfried AG & $-\quad-4$ & - \\
\hline Coatex P 50 & Coatex SA & $\begin{array}{l}\text { Sodium salt of a } \\
\text { polyacrylic acid }\end{array}$ & $\begin{array}{l}\text { Wetting/dispersing } \\
\text { agent }\end{array}$ \\
\hline Calgon N neu & $\begin{array}{l}\text { BK Giulini Chemie } \\
\text { (eh. BK Ladenburg) }\end{array}$ & $\begin{array}{l}\text { Sodium } \\
\text { polyphosphate }\end{array}$ & $\begin{array}{l}\text { Wetting/dispersing } \\
\text { agent }\end{array}$ \\
\hline Mergal K 15 & Troy Chemie $\mathrm{GmbH}$ & $\begin{array}{l}\text { Benzisothiazolon } \\
\text { basis, without } \\
\text { formaldehyde }\end{array}$ & Preservative \\
\hline Agitan 731 & $\begin{array}{l}\text { Münzing } \quad \text { Chemie } \\
\text { GmbH }\end{array}$ & - & - \\
\hline Tiona 595 & $\begin{array}{l}\text { Millennium Inorganic } \\
\text { Chemicals }\end{array}$ & - & - \\
\hline IOKAL U.F. & Ionian Kalk S.A. & $\begin{array}{l}\text { Amorphous } \\
\mathrm{CaCO}_{3}\end{array}$ & Filler / Extender \\
\hline Mowilith LDM 1871 ca.53\% & Clariant $\mathrm{GmbH}$ & VA/ethylene & Binder (copolymer) \\
\hline
\end{tabular}

Colour and optical measurements were carried out at the Research Center of Omya S.A. in Oftrigen Switzerland. Optical properties of surface coatings were measured on the film that coating creates when applied. These properties were measured on special cards with glossy surface. Half of their surface was coloured white and other half black. These cards have been established for measurement of the optical properties of coatings and provide reliable means of comparison for different colours. Tests were carried out in a white emulsion paint, of good quality, containing $18 \%$ of $\mathrm{TiO}_{2}$. The amount of the $\mathrm{TiO}_{2}$ was replaced gradually by adding $2 \% \mathrm{CaCO}_{3}$ filler each time. The remaining components of the formulation remained constant. At the beginning the composition of the formulation was: $33 \% \mathrm{w}$ deionized water, $18 \% \mathrm{w} \mathrm{TiO}, 36 \% \mathrm{w}$ other fillers (talc and calcium carbonate) and $13 \% \mathrm{w}$ binder and organic additives

\subsection{Mechanical resistance of surface coatings}

Wet scrub resistance (WSR) and film density were measured on the cards described before. The cards have a specific size so the area of the film is known. They are weighed before and after application of the colour and from the difference the mass of the colour that applied is calculated. The thickness of the film was $300 \mu \mathrm{m}$. After application of colour, the cards were placed in 
constant temperature $\left(23^{\circ} \mathrm{C}\right)$ and were left for 24 hours to dry out. From the thickness of each film and the area of the card the volume of the film (V) was calculated. Since the mass of the film (m) was known as mentioned before, the film density $\mathrm{d}$ was finally calculated.

For determination of WSR each card was subjected to 200 circles of wet scrub washing, after which the colour was measured and the mass loss was determined by weighing the cards. The smaller amount of film that is removed during wet scrubbing the greater the resistance of the film is. From the density of the film we calculated the thickness of the film that was removed under this test.

\section{Results}

\subsection{Replacement of $\mathrm{TiO}_{2}$ by calcium carbonate-optical properties}

The evolution of $\mathrm{R}_{\mathrm{x}}$ of films on white background with 300 and $150 \mu \mathrm{m}$ thickness, in which $\mathrm{TiO}_{2}$ had been gradually replaced by $\mathrm{CaCO}_{3}$ are shown in Figure $1 . \mathrm{R}_{\mathrm{x}}$ gradually decreases with increasing replacement of $\mathrm{TiO}_{2}$ by calcium carbonate. With increasing film thickness $\mathrm{R}_{\mathrm{x}}$ increases at all $\mathrm{TiO}_{2}-\mathrm{CaCO}_{3}$ mixtures. However in both cases the influence of replacement is not significant for replacement up to $50 \%$. For greater replacement of $\mathrm{TiO}_{2}$ by $\mathrm{CaCO}_{3}$ colour properties deteriorate significantly. This suggests that calcium carbonate can replace sufficiently $\mathrm{TiO}_{2}$ pigments in emulsion paints. Similar results were obtained for $R_{y}$ and $R_{z}$ parameters on white background and for $\mathrm{R}_{\mathrm{y}}$ on black background (data not shown).

The evolution of yellowness index $\left(b^{*}\right)$ with increasing replacement of $\mathrm{TiO}_{2}$ by calcium carbonate are shown in Figure 2. Yellowness index increases gradually with increasing calcium carbonate content for both film thicknesses. However again addition of calcium carbonate by up to $50 \%$ does not affect yellowness of the emulsion paint significantly. The $150 \mu \mathrm{m}$ thick film has a lower yellowness index for replacement of $\mathrm{TiO}_{2}$ by $\mathrm{CaCO}_{3}$ up to $80 \%$. For those coatings in which replacement of $\mathrm{TiO}_{2}$ exceeds $80 \%$ the thinner film has a higher yellowness index (Fig. 2).

The influence of replacement of $\mathrm{TiO}_{2}$ on the contrast ratio of the surface coating is shown in Figure 3. Like the previous properties replacement of $\mathrm{TiO}_{2}$ by calcium carbonate up to $50 \%$, does not affect significantly the contrast ratio of the surface coating. For all $\mathrm{TiO}_{2}-\mathrm{CaCO}_{3}$ mixtures the thicker films have greater contrast ratio compared to the thinner films.
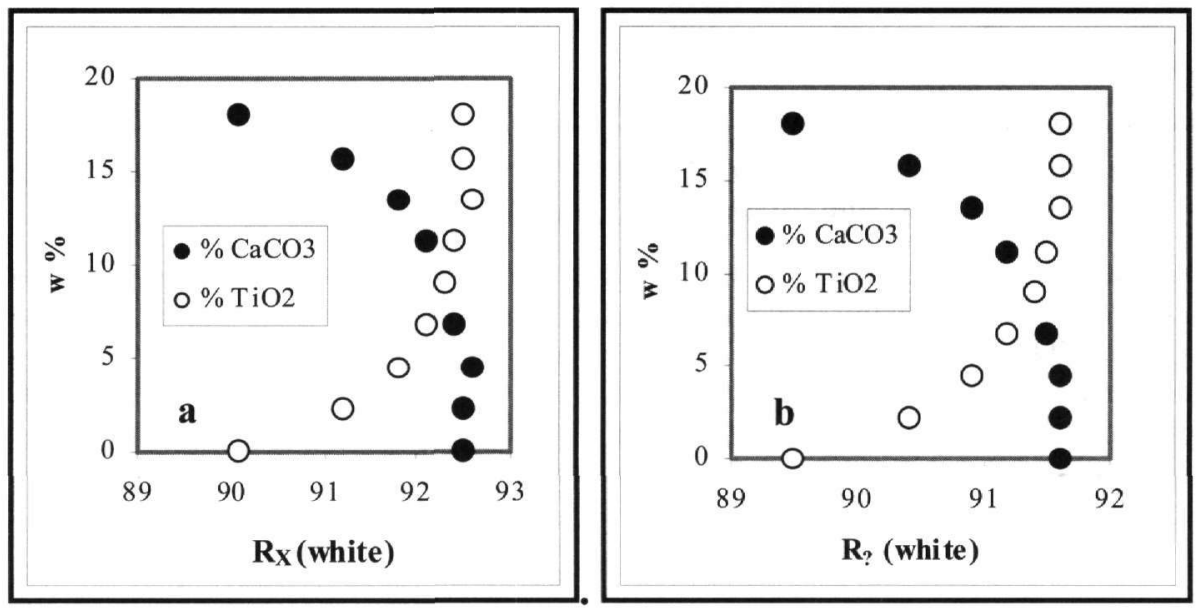

Figure 1 - Influence of replacement of $\mathrm{TiO}_{2}$ by $\mathrm{CaCO}_{3}$ on $\mathrm{R}_{x}$ of the surface coating. a) film thickness $300 \mu \mathrm{m}$ b) film thickness $150 \mu \mathrm{m}$ 

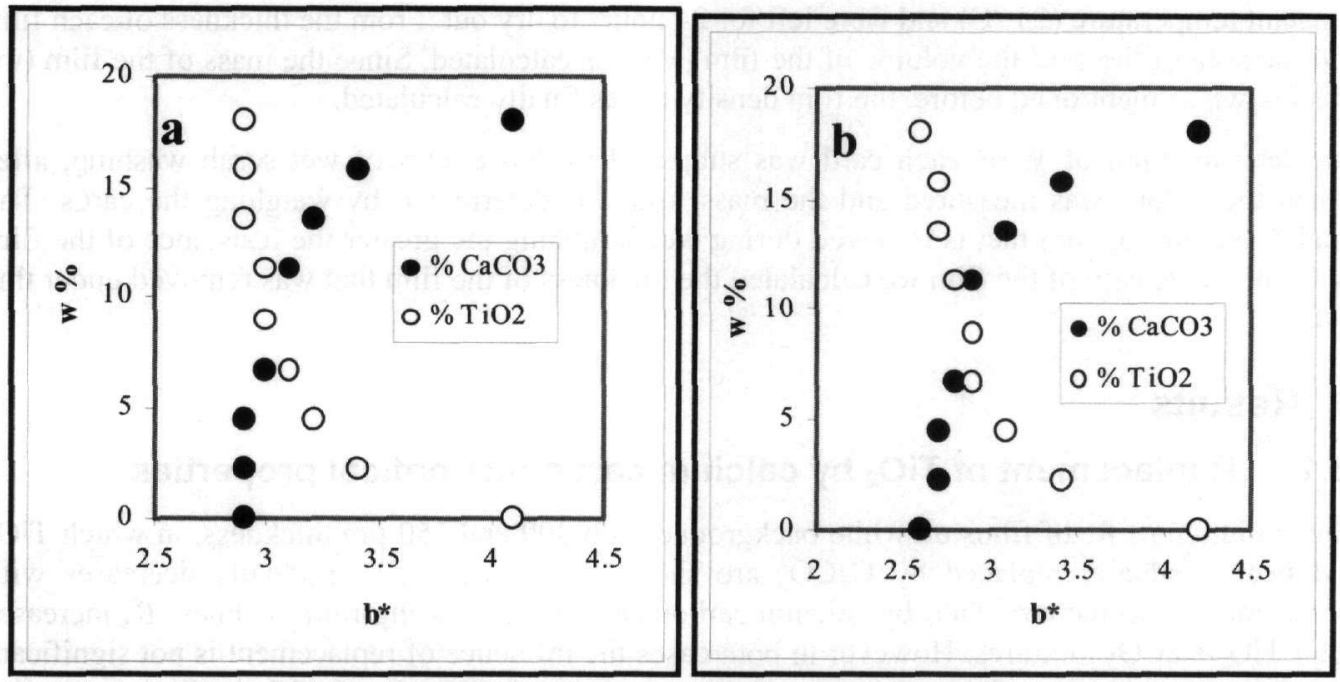

Figure 2 - Influence of replacement of $\mathrm{TiO}_{2}$ by $\mathrm{CaCO}_{3}$ on yellowness $\left(b^{*}\right)$ of the surface coating. a) film thickness $300 \mu \mathrm{m}$ b) film thickness $150 \mu \mathrm{m}$
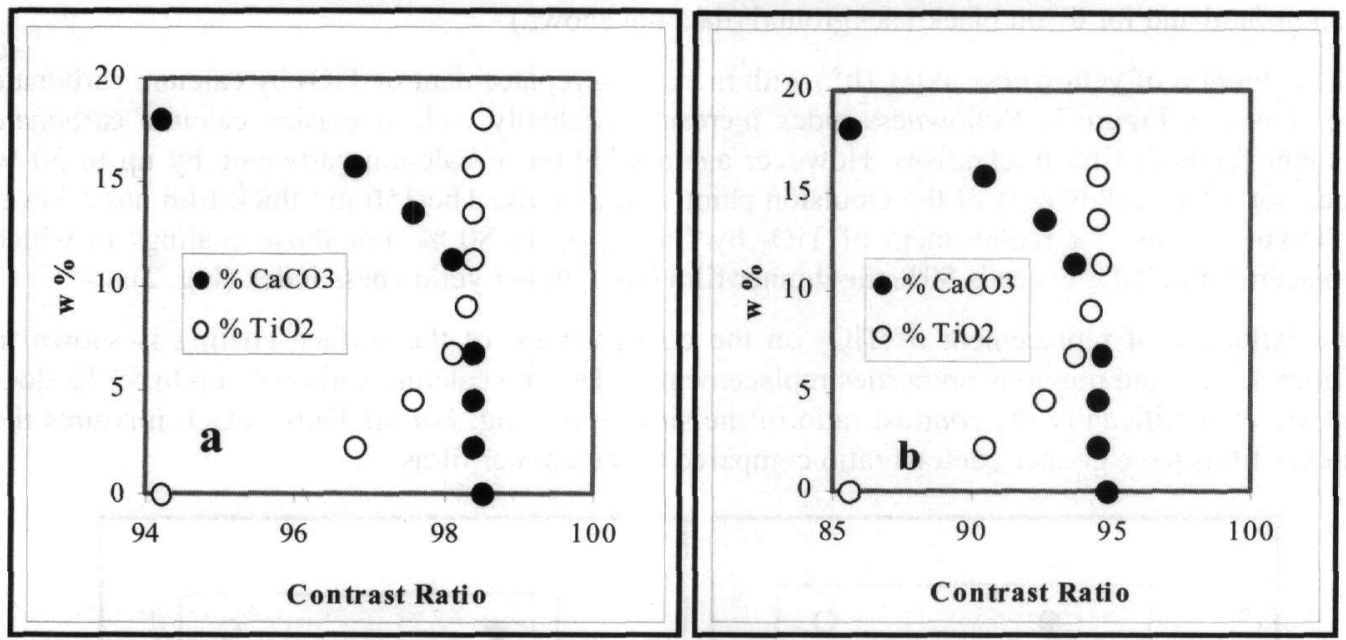

Figure 3 - Influence of replacement of $\mathrm{TiO}_{2}$ by $\mathrm{CaCO}_{3}$ on the contrast ratio of the surface coating. a) film thickness $300 \mu \mathrm{m}$ b) film thickness $150 \mu \mathrm{m}$

The influence of replacement of $\mathrm{TiO}_{2}$ on the gloss of the surface coating is shown in Figure 4 . Replacement of $\mathrm{TiO} 2$ by calcium carbonate affects also positively the gloss of the surface coating. Addition of $\mathrm{CaCO} 3$ is more important on the gloss of the coating compared to other optical properties, since it increases significantly even with small additions of $\mathrm{CaCO}_{3}$. Hence replacement of $\mathrm{TiO}_{2}$ by calcium carbonate by $50 \%$ yields an increase of gloss by $25 \%$. For all $\mathrm{TiO}_{2}-\mathrm{CaCO}_{3}$ mixtures the thicker films have greater gloss compared to the thinner films. 

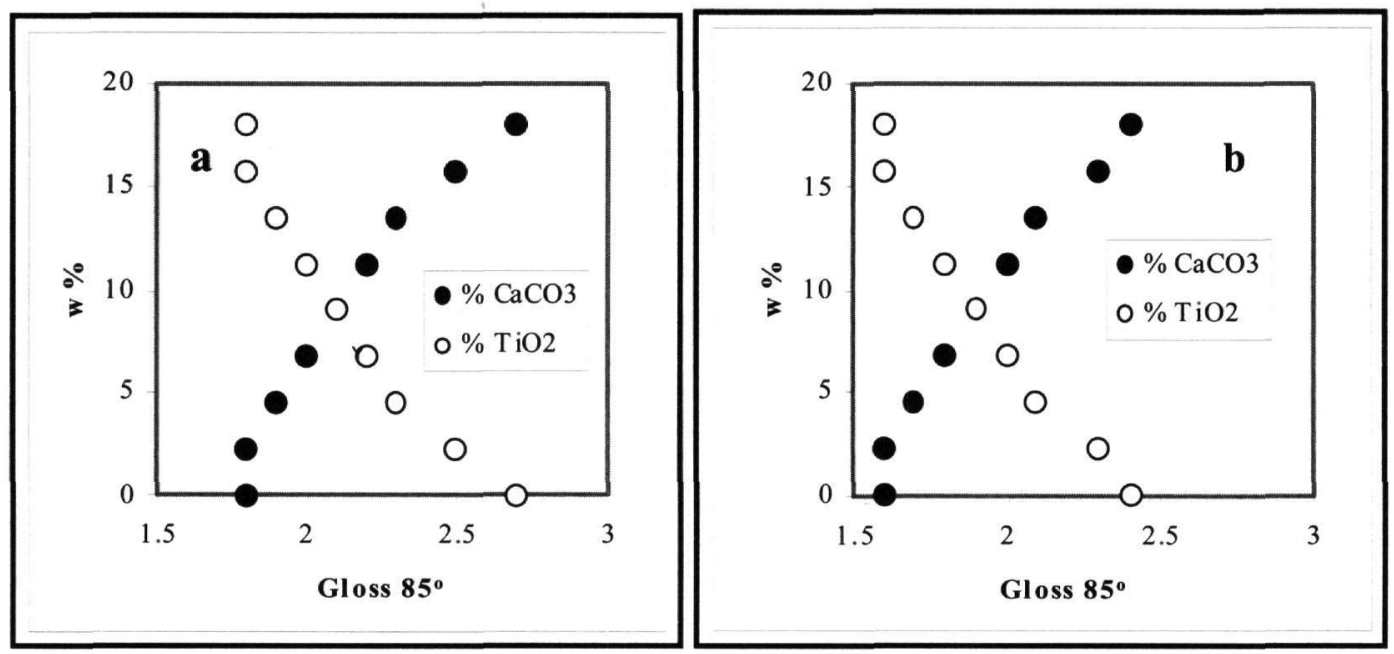

Figure 4 - Influence of replacement of $\mathrm{TiO}_{2}$ by $\mathrm{CaCO}_{3}$ on the gloss of the surface coating. a) film thickness $300 \mu \mathrm{m}$ b) film thickness $150 \mu \mathrm{m}$.

\subsection{Replacement of $\mathrm{TiO}_{2}$ by calcium carbonate-mechanical properties.}

The evolution of film density of surface coatings with thickness $300 \mu \mathrm{m}$, after replacement of $\mathrm{TiO}_{2}$ by calcium carbonate is shown in Figure 5a. Although we examined only three film compositions (the two end members and that composition with $\mathrm{TiO}_{2}: \mathrm{CaCO}_{3}$ ratio of $1: 1$ ), it is evident that replacement of $\mathrm{TiO}_{2}$ by $\mathrm{CaCO}_{3}$ increases film density. However, the influence is minimal for replacement up to $50 \%$, becoming more important thereafter, in full accordance with the optical properties. More specifically it increases from $1.763 \mathrm{~g} . \mathrm{ml}^{-1}$ to $1.82 \mathrm{~g} . \mathrm{ml}^{-1}$, whereas complete replacement of $\mathrm{TiO}_{2}$ yielded a film density of $2.014 \mathrm{~g} \cdot \mathrm{ml}^{-1}$.
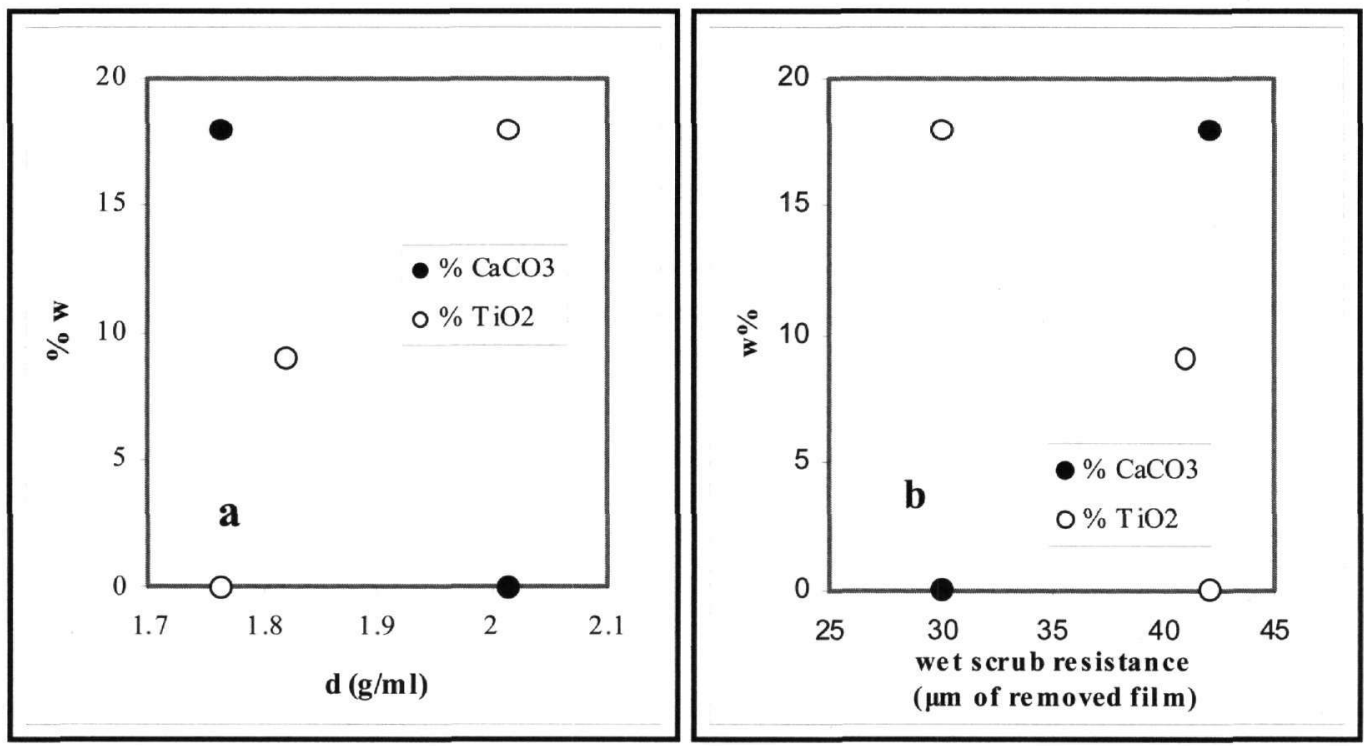

Figure 5 - Mechanical properties of the surface coatings. a) film density, b) wet scrub resistance

Replacement of $\mathrm{TiO}_{2}$ by calcium carbonate affected adversely the wet scrub resistance of surface coatings (Fig. 5b). Thus the thickness of film which was removed increases with increasing degree 
of replacement of $\mathrm{TiO}_{2}$ by calcium carbonate. This is expected because the hardness of rutile is considerable greater than calcite $(6-61 / 2$ and 3 respectively). Moreover the coatings employed on rutile $\left(\mathrm{Al}_{2} \mathrm{O}_{3}\right.$ and $\left.\mathrm{ZrO}_{2}\right)$ have even greater hardness than rutile. Note that replacement of $\mathrm{TiO}_{2}$ by calcium carbonate by $50 \%$ decreases wet scrubbing resistance by $33 \%$, whereas further replacement essentially does not affect the scrubbing resistance of the film. This suggests that scrubbing resistance depends also on other factors such as the organic binder and on the coherency of the film.

\subsection{Physical properties of the paint as fluid.}

Figure 6 shows the variation of pigment concentration per unit volume with increasing replacement of $\mathrm{TiO}_{2}$ by calcium carbonate. With increasing degree of replacement, the concentration of pigment per unit volume increases linearly, suggesting that it depends directly on the amount of calcium carbonate added. Nevertheless it is interesting that for replacement of $\mathrm{TiO}_{2}$ by $50 \%$ calcium carbonate (i.e. by 9 wt \%), pigment concentration per unit volume increases only by $1 \%$. This is important because pigment concentration per unit volume must remain constant in emulsion paints.

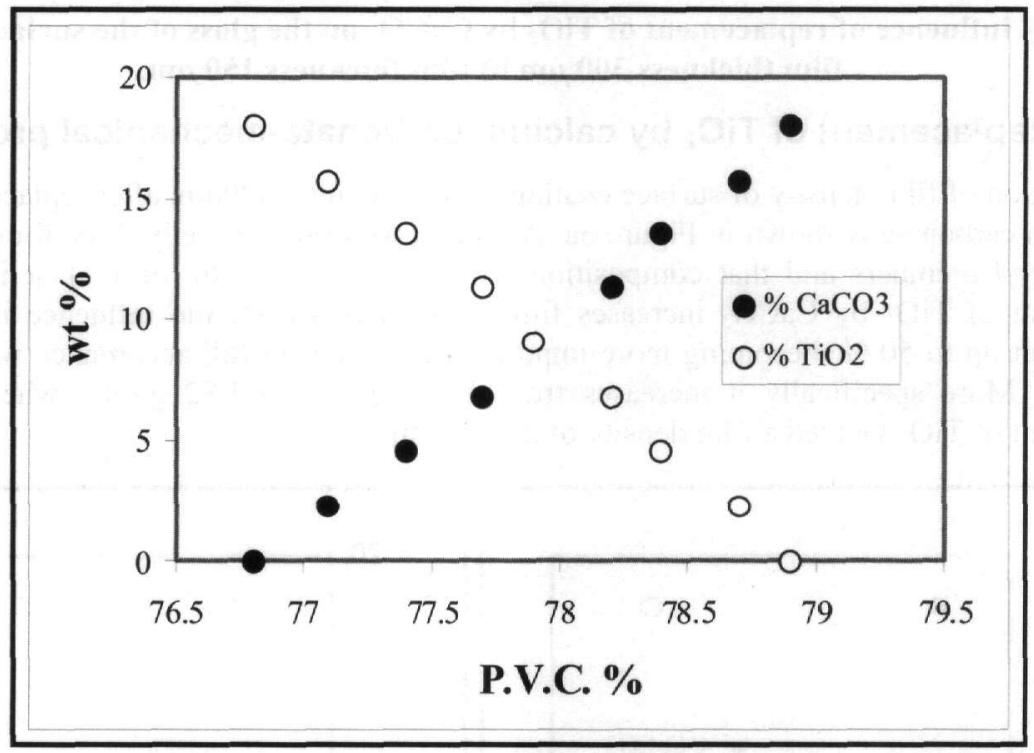

Figure 6 - Variation of pigment concentration per unit volume with replacement of $\mathrm{TiO}_{2}$ by calcium carbonate

Figure 7 shows the films of the emulsion paint containing blue pigment. The first film from the left consists of $18 \% \mathrm{TiO}_{2}$ and $0 \%$ calcium carbonate filler, the second film contains $9 \% \mathrm{TiO}_{2}$ and 9 $\% \mathrm{CaCO}_{3}$ filler and the third film on the right contains $0 \% \mathrm{TiO}_{2}$ and $18 \% \mathrm{CaCO}_{3}$ filler. It is obvious that the first and the second film are essentially inseparable since essentially they have the same hue without optical differences. In contrast total replacement of $\mathrm{TiO}_{2}$ by calcium carbonate yields a different hue. As a conclusion $\mathrm{CaCO}_{3}$ filler is capable of replacing $\mathrm{TiO}_{2}$ by $50 \%$ wt on an emulsion paint formulation.

\section{Discussion}

This work has shown that the chalky calcium carbonate from Kefalonia can be used not only as a filler or extender in emulsion paints but it can be a successful competitor for $\mathrm{TiO}_{2}$ pigment. Indeed it is clear in this study that it can replace a significant fraction of $\mathrm{TiO}_{2}$. The influence of this 
replacement can be distinguished in two parts, a) in the optical properties of the films and the physical properties of the emulsion fluid and b) in the mechanical properties of the films.

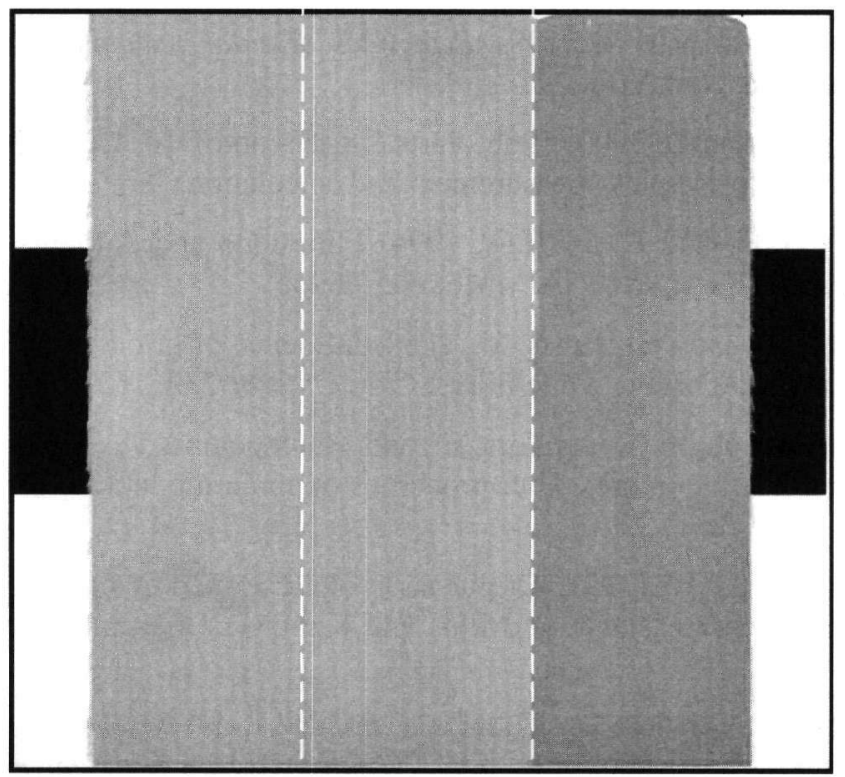

Figure 7 - Emulsion paint with blue pigment containing different proportions of calcium carbonate. The dashed lines indicates the boundaries of the three films

The optical properties and the physical properties of the emulsion are not affected significantly for replacement of $\mathrm{TiO}_{2}$ up to $50 \%$ (Figs 1-4). The slight deterioration of most of them is not considered important to create problems in the emulsion paints. In the case of pigment volume concentration (PVC) the observed minimal change $(1 \%)$ that is not adequate so as to reach or exceed the critical PVC value. This means that the colour properties of the paint as a fluid are not affected significantly. Moreover it confirms the excellent properties of calcium carbonate as extender in paints.

In contrast to the optical properties wet scrub resistance of the films is affected by replacement of $\mathrm{TiO}_{2}$ by calcium carbonate to a greater degree. Therefore the produced paints have a lower resistance and this can be a significant drawback for their quality. However this can be improved by use different types of binders or by addition of other fillers such as diatomite, kaolin and white mica. Diatomite has a greater hardness than calcite, and kaolin and white mica consist of phyllosilicates, which although may have comparable or even lower hardness than calcite, they have superior surface properties and thus can increase the wet scrub resistance of the films.

A significant consequence of the possible replacement of $\mathrm{TiO}_{2}$ by calcite is the cost reduction in the production of emulsion paints. The cost of $\mathrm{TiO}_{2}$ per kilo is $2.5 €$, whereas the cost of ultra finegrained calcium carbonate, which is considered a high added value product does not exceed $0.3 €$ per kilo ( $300 €$ per tone). Such a great difference in prices is expected to enhance replacement of $\mathrm{TiO}_{2}$ by calcium carbonate in emulsion paints.

\section{Acknowledgments}

All lab analysis was conducted in the Research Center of OMYA S.A. in Oftrigen Switzerland. Many thanks to Mr. Lehner and Mr. Gysau for all their help, guidance and hospitality. Last but not least we would like to thank all lab personnel of OMYA S.A. that assisted in this work. 


\section{References}

Bergman, H., 1964. Geological Map of Greece, Kefalonia Sheet, scale 1:50,000.

Billmeyer, F.W., and Saltzman, M., 1981 Principles of color technology, $2^{\text {nd }}$ edition. 1-23pp., Wiley Interscience, New York.

British Standards Institution BS3900, 1986. Parts D8, D9 and D10. Determination of colour and colour difference: principles, measurement and calculation.

Carr, D.D., Rooney, L.F., and Freas, R.C., 1994. Limestone and dolomite. In D.D. Carr (ed.), Industrial Minerals and Rocks, AIMME, 605-609pp.

Christidis, G., Makri, P., and Perdikatsis, V., 2004. Influence of grinding on the colour properties of talc, bentonite and calcite white fillers, Clay Minerals, 39, 163-175.

Christidis, G.E., Sakellariou, N., Repouskou, E., and Marcopoulos, Th., 2004. Influence of organic matter and iron oxides on the colour properties of a micritic limestone from Kefalonia, Bull. Geol. Soc. Greece, 36, 72-79.

Christidis, G., and Scott, P.W., 1997. Origin and colour properties of white bentonites: A case study from the Aegean Islands of Milos and Kimolos, Greece, Miner. Deposita, 32, 271279.

Naydowski, C., Hess, P., Strauch, D., Kuhlmann, R., and Rohleder, J., 2001. Calcium carbonate and its industrial applications. In F.W. Tegethoff (ed.), Calcium Carbonate. From the Cretaceous Period into the $21^{\text {st }}$ Century, Birkhäuser Verlag, Basel, 197-311pp.

Power, T., 1985. Limestone specifications. Limiting constraints on the market, Industrial Minerals, 217, 65-91.

Scott, P.W., and Dunham, A.C., 1984. Problems in the evaluation of limestone for diverse markets, $6^{\text {th }}$ Industrial Minerals International Congress, Toronto, Metal Bulletin, London, 1-21. 